\title{
MRTFB wt Allele
}

National Cancer Institute

\section{Source}

National Cancer Institute. MRTFB wt Allele. NCI Thesaurus. Code C142160.

Human MRT FB wild-type allele is located in the vicinity of 16p13.12 and is approximately $195 \mathrm{~kb}$ in length. This allele, which encodes MKL/myocardin-like protein 2, is involved in skeletal myogenesis. A translocation $\mathrm{t}(11 ; 16)(q 13 ; p 13)$ that fuses this gene to the C11orf95 gene is associated with chondroid lipoma. 